STATE OF ALASKA

DEPARTMENT OF NATURAL RESOURCES

DIVISION OFI GEOLOGICAL AND GEOPHYSICAL SURVEYS

JUNE 1973

This report is prellminary and has not been edited or reviewed for conformity with Alaska Gcological \& Geophysical Surveys standards.
Alaska Open File Report 19

AEROMAGNETIC MAP,TALKEETHA QUADRANGLE ALASKA 


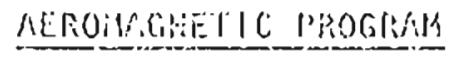

(1): TIII:

DIVISIOH UR GROLOGIEAL E GEOPHYSICAL SURVEYS

The Alaska Geological and Cocophsical Surveys Acromanetic Program is - 100\% State funded exploration project that was started in 1971. Under the direction of the Survey, an aeromagnet ic contractor flies the aeromagrelic profiles, compiles lise data and prints the maps.

Two hundred (200) maps at $1: 63,360$ scale are printed for 5 ald by the Survey and when this supoly is gone an original mylar of cach map will be open filed. A composite 1:250,000 map of each USGS quadrangle is also mad: and open filed as soon as completed. 


\section{TECHNICAL INFORMATION}

1971 - 1973 OATA

The survey flight 1 ines are spaced $3 / 4 \mathrm{mile}$ apart and 1000 feet above ground level where possible. Tie lines were flown at $15^{\circ} \mathrm{mile}$ intervals normal to the flight lines. The fluxgate magnetometer signal was recorded in flight on a paper strip chart recorder. The diurnal varlation was recorded by a ground station. Aircraft aititude was determined by radio altimeter and recorded in flight on a paper strip chart recorder. Aerial photography on $35 \mathrm{~mm}$ black and white film at 3 -second intervals was used to plot the aircraft flight path. The regional field was removed from the magnetic data and corrections were made for diurnal variation.

1974 DATA

Survey lines were flown 1 mile apart with 15 mile tie lines. Data recorded digitally. Maps digitally contoured. Details of digital recording and processing available on request.

The original field data are kept in the Division of Geological and. Geophysical surveys offices and may be copied at the expense of the interested person.

For information concerning the aeromagnetic program, contact the state. Geological and Geophysical Surveys, 3001 Porcupine Drive, Anchorage, Alaska 99501 , telephone (907) 279-1433. 


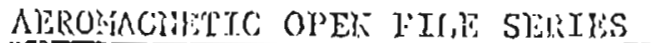

$$
\langle .1: 250,000\rangle
$$

\section{OLET EIIE}

1

2

3

4

5

6

7

8

9

10

11

12

13

14

15

16

17

18

19

20

21
DATE FLOTIN

1971

1971

1971

1971

1971

1971

1971

1971

1971

1971

1971

1971

1971

1971

1971

1971

1971

1972

1972

1972

.1972
QUADDRANGIEE

Selawil:

Teller

Bendeleben

Candle

Nome

Solomon

lorton bay

Fairbanks (south)

liealy

Mt. Jlayes

Tanacross

Gulkana

Nabesna

Bethel

Goodnews

Hagemeister Islar.

Nushagak Bay

Eagle

Talkeetns

Talkeetna rits.

Anchorage 


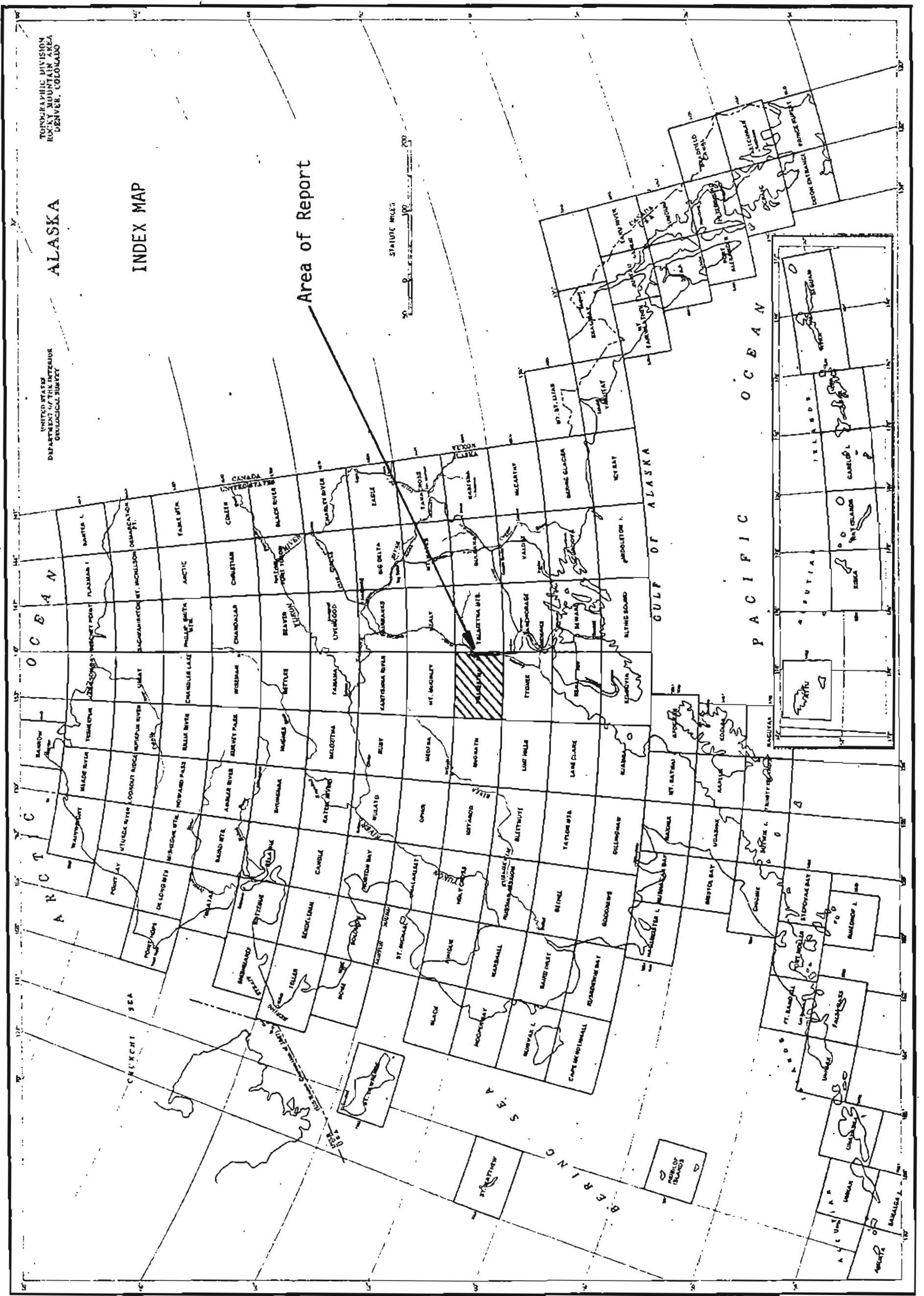

